\title{
Evaluating ecosystems services values due to land use transformation in the Gojeb watershed, Southwest Ethiopia
}

\author{
Hailu Shiferaw* (10, Tena Alamirew, Tibebu Kassawmar and Gete Zeleke
}

\begin{abstract}
Background: Land use land cover (LULC) transformation and ecosystems service valuation (ESVs) play important roles for vegetation restoration and design restoration options such as payment for ecosystems service programs. The objective of this work was to quantify LULC transformations and associated ESVs in the Gojeb sub-basin by analyzing LULC between 1986 and 2016 using satellite images, field observations and ancillary datasets. And Ecosystems service valuations of different land use types were carried out using benefit transfer method.

Results: The summarized LULC classes are: bareland, cropland, grassland, forest, plantation, settlement, shrub, waterbody and woodland. The ESVs were evaluated for each LULC based on these LULC classes. Forests had the highest cover (> 423,000 ha 60\%) in 1986 but it reduced to 317,000 ha ( 45\%) in 2016. About $>56,000$ ha of forests were changed to cultivated land, and $>105,000$ ha to different classes. Cultivated land increased to $>258,000$ ha $(\sim 37 \%)$ in 2016 compared to 150,000 ha $(\sim 21.5 \%)$ in 1986. The sub-basin had ESVs of US 2.52 billion in 1986 but decreased to US\$ 1.97 billion in 2016; losing about US\$ 0.551 billion within the last 30 years (annual loss rate of US\$18.4 million). Potential drivers would be agricultural expansion, land degradation/erosion, landslide and deforestation, indicating that requires concerted effort to restore and manage landscapes for sustainable socio-ecological and economic uses.

Conclusion: This study is meaningful for management of natural resources in the catchment, improvement of hydropower production and lifespan of the hydropower reservoir besides to improving land productivity for small holder farmers as hydrological cycles and biodiversity components of the catchment can be improved. This study assist policy makers in designing evidence-based programs such as payment for ecosystem services in the study area and elsewhere.
\end{abstract}

Keywords: Ecosystems service valuation, Ethiopia, Gojeb watershed, Land use land cover, Omo-Gibe Basin, payment for ecosystem services

\section{Highlights}

- Forest area had the highest cover 60\% in 1986 but it was reduced to $45 \%$ of the watershed in 2016.

- About $>105,000$ ha of forest were changed to different land use types. Of which, more than $50 \%$ were changed to cultivated land.

*Correspondence: Hailu.S@wlrc-eth.org; Hailu2nd@gmail.com Water and Land Resource Centre, Addis Ababa University, P.O.Box 8707, Addis Ababa, Ethiopia
- Cultivated area increased from $21.5 \%$ in 1986 to $37 \%$ in 2016.

- The watershed had ESVs of US\$ 2.52 billion in 1986 but decreased to US\$ 1.97 billion in 2016.

- The watershed lost about US\$ 0.551 billion within the last 30 years, with annual loss rate of US\$ 18.4 million.

- This will assist policy makers in designing evidencebased solutions for any development interventions or payment for ecosystem service programs in the study area. 


\section{Background}

An increasing demand for agricultural, industrial or urban areas compromises the ability of natural forests, waterbodies and grasslands to support mankind (Nelson et al. 2009; Goldman-Benner et al. 2012), which cause land use/cover changes either permanently or temporally. In recent decades, substantial area of land use land cover (LULC) changes have been observed due to different socio-economic and biophysical drivers.

In sub-Saharan Africa, some studies have been conducted on mapping and valuation of ecosystem services (ES) in the context of LULC changes (Arowolo et al. 2018; Hulme et al. 2013; Leh et al. 2013; Kindu et al. 2016; Tolessa et al. 2017; Silvestri et al. 2013). Almost all studies indicate that this region is under severe pressure of degradation with significant consequences for rural livelihoods (Scholes et al. 2018). For example, Sutton et al. (2016) estimated for Ethiopia a loss of $17.7 \%$ in ecosystem service values (ESVs) due to land degradation, which is also reflected in studies conducted in different parts of Ethiopia (Gashaw et al. 2018; Kindu et al. 2016; Tolessa et al. 2017). Drivers of land degradation in subSaharan Africa include the expansion of crop production, unsustainable grazing and forestry practices and climate change (Scholes et al. 2018).

Species-rich ecosystems are able to simultaneously provide multiple ES (Lefcheck et al. 2015). If LULC changes negatively affect biodiversity and the provisioning of these ES or promote ecosystems disservices (EDS), they also reduce the overall value of the land. According to The Economics of Ecosystems and Biodiversity (TEEB) report by 2010, recognizing value in ecosystems, landscapes, species and other aspects of biodiversity is a feature of all human societies, communities and sometimes sufficient to ensure conservation and sustainable use. Over the last 20 years, many ecosystem service values (ESVs) studies have been carried out at global, national or subnational levels (Schmidt et al. 2016), and some of which integrating spatially explicit approaches (Kremer et al. 2016; Liu et al. 2009).

A suggestion made by Braat and Groot (2012) indicates that decisions regarding the future use of an ecosystem should consider the full costs and benefits for the wellbeing of the current and future generations. Ecosystem services are the products of complex interconnected social-ecological systems (Grêt-Regamey et al. 2015), indicating that evaluating ESVs requires a deep understanding of the social-ecological systems and the dynamics of the relationship between human activities and the ecosystems under consideration (Grêt-Regamey et al. 2015; Maes et al. 2012; Shackleton et al. 2016; Vaz et al. 2017). Hence, understanding ES and their values as well as their spatial dynamics will explicitly contribute towards considering ES for policy goals and measuring welfare of society both at local and national levels (Niquisse et al. 2017).

In sub-Saharan Africa, some studies have been conducted to estimate ES in the context of LULC changes (Arowolo et al. 2018; Hulme et al. 2013; Leh et al. 2013; Kindu et al. 2016; Tolessa et al. 2017; Silvestri et al. 2013). Most of these studies indicate that this region is under critical challenges of degradation, with significant response to rural livelihoods (Scholes et al. 2018). For instance, Ethiopia lost about $17.7 \%$ in ESVs due to land degradation (Sutton et al. 2016), which is also reported in studies conducted in different parts of the country (Gashaw et al. 2018; Kindu et al. 2016; Tolessa et al. 2017). Drivers of land degradation include the expansion of cultivated land for crop and timber productions, overgrazing, and climate change (Scholes et al. 2018).

Quantification of ESVs based on the ES database (Van der Ploeg et al. 2010) is commonly undertaken by integrating LULC data of biomes present in a region of interest (Costanza et al. 2014; Van der Ploeg et al. 2010). Although these biomes are not exactly similar in their characteristics and functions with the LULC types used in different studies, average values per unit area derived from valuation studies for a particular biome can be used as proxies for estimating the ESVs of the corresponding LULC types (Tolessa et al. 2017). Analyzing LULC changes in the upper catchment is very critical to the downstream users as resources flow from upper to down catchment include water and sediment. In this regard, the downstream users should also contribute to the watershed management practice carried out by the upper stream users for the sustainable use of the common resources. Ecosystem is an ecological reservoir with a great regulation capacity. Dams in the lower catchment cannot completely replace the reservoir water conservation function of ecosystems, and has high economic and environmental costs that must be paid as well (Fu et al. 2014). This is a new concept introduced into the watershed practices as well as bigger basin management solutions is payment for ecosystem services. That is, the future analyses are focused on interlinking upper and downstream users by means of payment for ecosystem service (PES).

This study aimed at assessing ESVs values by analyzing LULC changes in the Gojeb watershed of Omo-Gibe sub-basin, southwest Ethiopia, and quantifying the consequences on ESVs. Landsat satellite data of two periods: 1986 and 2016 were used to quantify changes in LULC over the last 30 years. Moreover, two related objectives were targeted: (i) assessing LULC dynamics, calculate its gains, losses and net changes in area of the different LULC types, (ii) estimating the ESV changes caused by 
LULC dynamics in the study area in order to assist policy makers in designing evidence-based solutions such as for the 'payment for ecosystem service (PES)' schemes to be implemented in the near future as the watershed is under hydropower generation catchment.

\section{Materials and methods}

\section{Study area}

This study was conducted at Gojeb watershed in the Omo-Gibe sub-basin in the southwest Ethiopia (Fig. 1). The Gojeb River catchment (a tributary of the Omo River) is covering an area of about 700,000 ha. Geographically, the catchment is located between 35.36 and $37.34^{\circ} \mathrm{E}$, and 07.02 and $07.53^{\circ} \mathrm{N}$ with altitudinal range of 806 to 3348 m.a.s.l. The catchment lies in two regional states, i.e., the Southern Nations, Nationality and Peoples Region (SNNPR) and Oromia Region. Climate of the study area is generally classified as tropical cool humid. The agroecology of the catchment consists of cold moist (around the upper catchment of Gojeb River), hot moist (the middle portion of the southern part of the catchment) and wet moist (the remaining substantial part of the catchment). Annual rainfall varies from about $1000 \mathrm{~mm}$ in the extreme south to over $1850 \mathrm{~mm}$ in the highland northern parts of the catchment with the average being over $1450 \mathrm{~mm}$ (Yilikal 2019).

The study area covers about 700,000 ha in the Gojeb watershed in the Omo-Gibe-sub-basin (Fig. 1). Gojeb River is partly bordering Oromia and SNNP regions. The detailed analysis of land use transformation of the watershed was identified for more than 25 land use/land cover types (Table 1) as small as 0.03 ha and as large as 269,499 ha of land with $30 \mathrm{~m}$ spatial resolution and within 30 years' time span. These detailed land use land cover classes were also summarized into commonly used corresponding land use land cover types.

\section{Land use datasets and classification approaches}

Satellite data were preprocessed using the Google Earth Engine (GEE) cloud computing environment. The Landsat Ecosystem Disturbance Adaptive Processing System (LEDAPS) was used for surface reflectance products (Lu et al. 2002) of Landsat 5 TM, Landsat 7 ETM + and Landsat 8 OLI, provided by USGS. All images were corrected

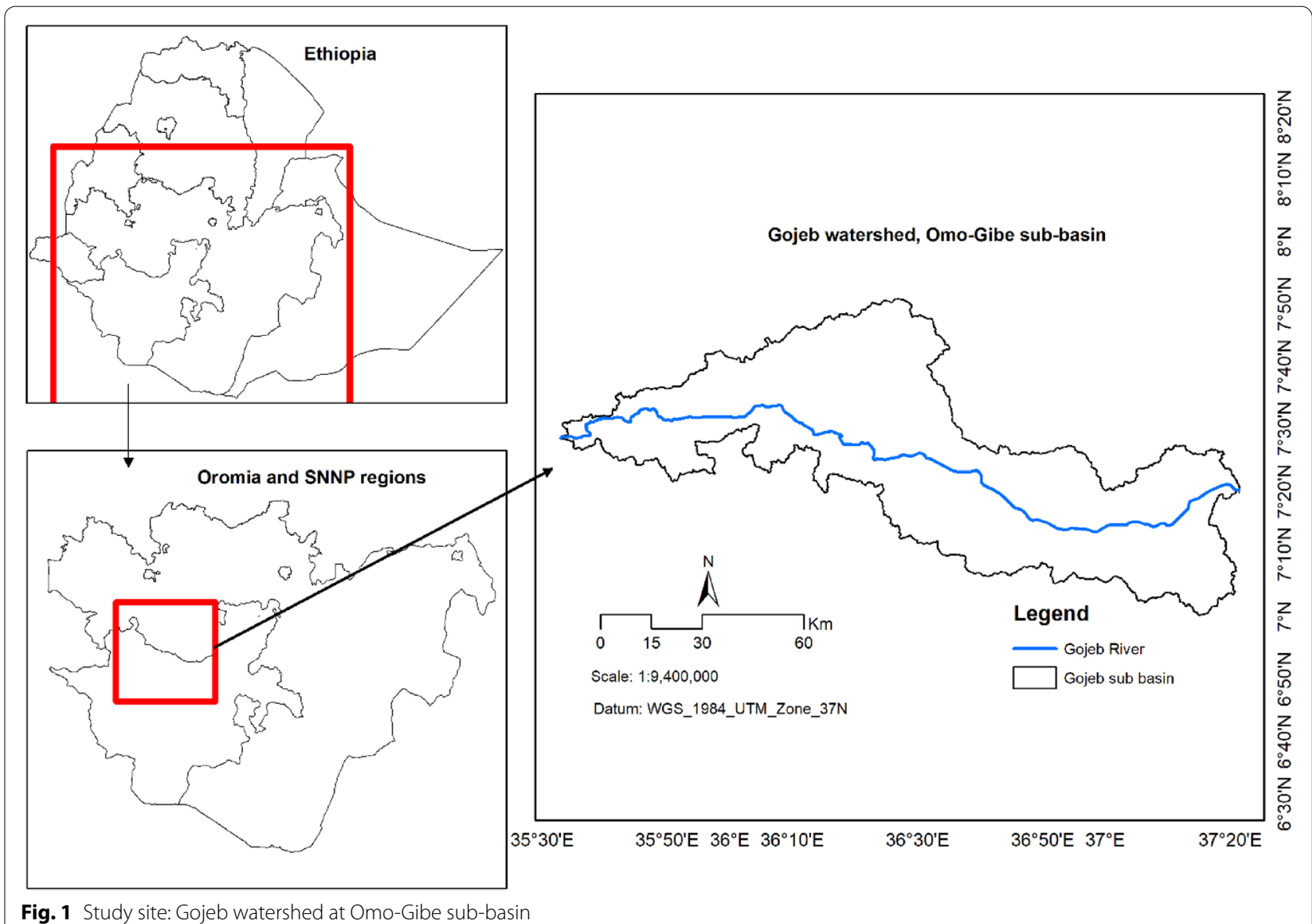

Fig. 1 Study site: Gojeb watershed at Omo-Gibe sub-basin 
Table 1 Descriptions of detailed LULC class names (Level II) and corresponding LULC names (Level I)

\begin{tabular}{|c|c|c|c|c|c|}
\hline $\begin{array}{l}\text { Class name } \\
\text { (Level II) }\end{array}$ & Description & $\begin{array}{l}\text { LULC name } \\
\text { (levele I) }\end{array}$ & $\begin{array}{l}\text { Class name } \\
\text { (Level II) }\end{array}$ & Description & $\begin{array}{l}\text { LULC } \\
\text { name (Level I) }\end{array}$ \\
\hline Afcf & Agroforestry dominated by coffee & Cropland & Hghf & High forest & Forest \\
\hline Afec & Agroforestry enset and coffee & Cropland & Homp & Home garden planation & Plantation \\
\hline Afen & Agroforestry dominated by enset & Cropland & Mixf & Mixed forest & Forest \\
\hline Agrf & Agroforestry & Cropland & Pfor & Plantation forest & Plantation \\
\hline Bare & Bareland & Bareland & Rive & River courses & Forest \\
\hline Crhil & Crop in the hillside & Cropland & Rivf & Riverine forest & Forest \\
\hline Crwt & Crop with trees & Cropland & SBdn & shrub-bush dense & shrubland \\
\hline Csht & Cultivated with shifting & Cropland & SBop & Shrub-bush open & Shrubland \\
\hline Cwot & Crop without trees & Cropland & SeTT & Settlement & Settlement \\
\hline Dghi & Degraded hills & Shrub & Swmp & Swamp Waterbody & \\
\hline Dryf & Dry forest & Forest & Wate & Waterbodies & Waterbody \\
\hline Gdry & Grassland drained & Grassland & Wldn & Woodland dense & Woodland \\
\hline Gsvn & Grassland savanna & Grassland & Wlop & Woodland open & Woodland \\
\hline Gwet & Grassland wet & Grassland & & & \\
\hline
\end{tabular}

for geometric co-registered, ortho-rectification, and atmospheric correction. Images were provided together with a cloud mask and a quality assessment (QA) bands. We generated two different image collections having $30 \mathrm{~m}$ spatial resolution. In order to secure cloud-free dry season composites of surface reflectance, we had to include at least two years of imagery to represent each point in time. Thus, for 1986, we selected imagery acquired between 1985 and 1987 giving preference to pixels captured in 1986; and for 2016 we used data acquired from 2016 and 2017, with the majority of pixels taken from 2016 imagery. Then, we used the LEDAPS QA band to remove clouded pixels, resulting in a stack of cloud-free pixel values for each pixel location (Shiferaw et al 2019). The use of the median pixel value ensured that outlier values were excluded. This was done for each optical Landsat band. The reasons for our choice of two time periods (1986 and 2016) were: (1) the availability of cloud-free, good quality satellite images of the area since 1986, and before this period, there was no much development intervention happened in the area, thus, 1986 could be used as a baseline, and (2) 2016 has been a year of different environmental and development interventions have been occurred including Gibe III due to hydropower dam construction, and this year could indicate as the major IULC transformation could be happened.

Hence, Landsat $30 \mathrm{~m}$ satellite images analyses were conducted between 1986 and 2016 to monitor 30 years land use transformation using the advantages of remote sensing and geographic information system. They provide wide ranges of opportunities to produce LULC data at various scales. However, generating complete and comprehensive LULC information via remotely sensed data that fill the wide range of the need still faces difficulties (Jensen 1996; Renison et al. 2004). In Ethiopia, two major categories of challenges limit the potential of remote sensing techniques to produce the required scale and accuracy of LULC information: (1) landscape complexity (topographic and farming system) and (2) accessibility of better resolution remotely sensed data and suitable classification approach (Kassawmar et al. 2016a). Experiences shows that a stratified mapping approach can potentially address the challenges encounter when mapping heterogeneous and large areas (Homer et al. 2000; Lu et al., 2015).

Deriving Homogenous Image Classification Units (HICUs) was used that subdivided each Landsat image into smaller units where similar land cover mosaics occur was found to be a suitable classification approach (Kassawmar et al. 2016a). These land features were grouped into detailed and majority classes based on the occurrence, dominance and distribution of the land features. This requires disaggregation of classes at multiple steps of classification, which could allow capturing smaller classes that are commonly ignored in large and complex landscape mapping. The extracted classes were combined and areas of their occurrence masked within each Landsat image so that they would not distort the further classification process (Table 1).

This different approach has shown a considerable improvement on the accuracy of classification in complex landscapes. However, accuracy of classification could be more improved based on the number and precision of segments developed for every scene and local knowledge 
of the area (Kassawmar et al. 2016a). In complex landscapes traditional classification techniques that apply on full scene as unit of analysis have shown limitations due to spectral variability of features related to bio-physical complexity observed in a scene (Kassawmar et al. 2016b).

For the classification of satellite images, reference data were collected for training and validation of each major LULC type in the study area. Reference data for 1986 were collected from aerial photographs captured in 1986. Careful attention was paid to collect only reference data using pure pixels of $30 \times 30 \mathrm{~m}$ for each LULC type. Reference samples for 2016 were derived from the LULC maps of the Ethiopian Mapping Agency (EMA, 2013) and some additional data for 2016 period were collected from more dynamic cover types using a handheld GPS (Garmin GPSMAP 60CSx) as part of the national LULC mapping. More than 150 plots were considered for each years of 1986 and 2016. Field samples were partitioned and used for calibration (70\%) as well as validation (30\%) (Olecka 2003; Oleksy 2017). The LULC classifications for the two points in time were carried out using supervised classification approach on acquired satellite images and ground truth data. After classification, LULC changes were calculated for two different time periods, i.e. 1986, 2016, and 1986-2016, were made using cross tabulation and calculating percent changes for each LULC type over time (Gashaw et al. 2018; Kindu et al. 2016; Temesgen et al. 2018). Then major classes were generated from the detailed (Level II) classification result carried out. Accuracy assessment was carried out and an overall accuracy of more than $85 \%$ was achieved (Kassawmar et al. 2016b).

LULC changes were calculated using cross-tabulation (Kindu et al. 2016; Shiferaw et al. 2019). LULC changes were calculated for two different time periods between 1986 and 2016 as methods applied by different studies (Eckert et al. 2017; Kindu et al. 2016; Shiferaw et al. 2019) and calculating percent changes for each LULC type over time (Gashaw et al. 2018; Kindu et al. 2016; Temesgen et al. 2018) (Eq. 1).

$$
\text { Percent of change }=\frac{A 2-A 1}{A 1} X 100
$$

where, $A 1$ is area of land use and land cover type (ha) in year 1 (in 1986), $A 2$ is area of land use and land cover type (ha) in year 2 (in 2016).

Furthermore, class-specific gains, losses, and stable areas, as well as total change area and net changes of the total area analyzed were calculated (Alo and Pontius 2008; Zewdie and Csaplovics 2015). Annual change rates were calculated for each LULC type following Puyravaud (2003) and Tilahun et al. (2014), i.e. the rate of change for a specific class was calculated by dividing the class-specific changes between two time intervals by the number of years between these two observed points in time (Eq. 2).

$$
\text { Rate of change }=\frac{A 2-A 1}{Z}
$$

where, $A 1$ is area of land use and land cover type (ha) in year $1, A 2$ is area of land use and land cover type (ha)in year $2, Z$ is the time interval between $A 1$ and $A 2$ in years.

\section{Ecosystem serving values}

In this study, the benefit transfer approach was used to estimate ecosystems service values (ESVs) of different LULC types and their changes (Costanza et al. 1997, 2014; Niquisse et al. 2017). The benefit transfer approach refers to the process of using existing values and other information from the original study site to estimate ESVs of other similar locations in the absence of site specific valuation information (Bagstad et al. 2013; Niquisse et al. 2017). We calculated the ESVs of the LULC types in Gojeb catchment by adapting the coefficients of tropical areas on regional estimates of ESVs using data provided by Kindu et al. (2016), who conducted a study on LULC and ESVs in Ethiopia using conservative estimates of ESV coefficients, which were based on values from studies conducted in areas similar to the geographical setting of our study area. These ESVs include the main three ES: supply, regulation/monitoring and provision (Kindu et al. 2016) and also using the updated global coefficients provided by Costanza et al. (2014). Land use types such as bare land and settlement did not have a coefficient in some studies (Costanza et al. 1997; Kindu et al. 2016; Tolessa et al. 2017). Hence, the ESVs for all LULC types were calculated for each period using the following Equation (Costanza et al. 1997, 2014) and similar to studies conducted for tropical forests provided by Costanza et al. (2014) and that for woodland/shrub land provided by Temesgen et al. (2018) (Eq. 3):

$$
\mathrm{ESV}=\sum_{k=0}^{n} A k(V C k)
$$

where, $E S V$ is estimated ecosystem service value, $A k$ is the area (ha) of LULC type $k$, and $V C k$ is the value coefficient (Appendix 1) in US\$ ha ${ }^{-1}$ yearr $^{-1}$ for LULC type $k$.

\section{Results}

Land use land cover transformation

Land transformation analysis of Gojeb watershed within the last 30 years indicated that shrub-bush land and woodland were mainly changed to croplands of different uses. Of the 700,000 ha of the watershed, still 292,052 ha 
(41.7\%) of land is covered with high forest by 2016 although high forest area was 346,388 ha (49.5\%) in 1986. About 56,013 ha of high forest area were changed to different cultivated land such as agroforestry, cropland and cropland with and without trees. Cultivated area covers the second largest areas 258,395 ha (37\%) in 2016 as compared to 150,144 ha (21.5\%) in 1986 (Fig. 2). On the other hand, bare-land also increased from 14.5 ha in 1986 to more than 1400 ha in 2016 indicating that there is a great de-vegetated activities carried out in the watershed for the last 30 years.

About 161 ha of land was occupied with settlements in 1986 while this becomes more than double (383 ha) in 2016. Swamped and water-bodies were covered more than 755 ha in 1986 but were significantly reduced in 2016. Agroforestry groups were covered about 39,682 ha in 1986 and these increased to 53,956 ha in 2016 with the expenses of shrub-bushland, woodland and high forest. Cropland (hillside cultivation crop with trees and without trees) has gained double coverage that accounted for 204,438 ha in 2016 while it was 110,462 ha in 1986 with the expenses of dry grassland, shrub-bush land and woodland.

The forest in general and the dry forest cover in particular was lost more than 105,000 ha in the eastern part of the watershed, which has very important role in soil conservation and harbors for biodiversity hotspot. It is significantly reduced in 2016, and replaced by cultivation and open woodland areas. Of the 41,000 ha of dry forest in 1986, ca. 4700 ha was changed to cultivation, 15,000 ha to shrub-bush, 14,000 ha to woodland and the rest changed into different land use types (Table 2). Forest lost about $15 \%$ of its cover in 2016 (45\%) as compared to $1986(60 \%)$. Woodland lost half of its area in 2016 . The annual rates of reduction were about $-3525,-1262$ and - 21 ha from forest, woodland and grassland, respectively. On the other hand, bare-land, cropland, plantation, settlement, shrubland and water-body increased in their coverage in 2016 by constraining forest and woodland. The highest land transformation or conversion was observed on forest (ca - 3525 ha/year) and cropland (+3608 ha/year).

There were very dynamics in the land use changes of the Gojeb watershed. Looking at the details of deforestation processes, high forest and dry forest of the sub-basin were cleared dramatically (Fig. 3). Mainly dry forest (dry area/lowland forest) are totally disappeared in 2016, and woodland decreased by half. These have been happened mainly around the middle and eastern part of the basin. On the other hand, LULC transformation matrix from which to which (Table 3) indicates that bareland was accounted about 2 ha in 1986 but grown more than 600 ha in 2016. Similarly, plantation and settlement areas increased five and twice, respectively from the base 1986.

\section{Ecosystem service values}

After we summarized the detailed land use land cover types into nine classes, grassland, forest and woodland lost high amount of values in 2016 as compared to 1986 whereas cropland, settlement and shrub/bushland gained. As a watershed, Gojeb watershed gave about US\$ 2.52 billion in 1986 but it decreased to US $\$ 1.97$ billion in 2016. The watershed lost about US\$ 0.551 billion within the last 30 years (Table 4). The annual loss of US\$ 18.4 million was estimated, the major loss was found from forest and woodland reduction, with about US\$ of - 569 million, and US\$ of -37 million, respectively.

\section{Discussions}

Our assessment of LULC changes in the Gojeb watershed revealed a significant degradation of ES over the last 30 years and a high associated loss of ESVs. The most important change in land cover has occurred in reductions of forest and increasing of cropland. Bareland may have historically exhibited low levels of vegetation or may have been degraded already due to anthropogenic effects. Hence, our results provide evidence that agriculture can be a key driver of LULC change and associated losses of ESVs at the study area and elsewhere with similar environmental and socio-economic settings.

\section{Land use land cover transformation}

Land use land cover (LULC) changes are aspects of global environmental change and affect ecosystem processes and services. For example, an increasing demand for agricultural, industrial or urban areas compromises the ability of natural forests, waterbodies and grasslands to support mankind (Nelson et al. 2009; Goldman-Benner et al. 2012). In recent decades, a large amount of change in LULC has been observed, which was caused by different socio-economic and biophysical drivers, such as population growth, agricultural expansion and intensification (Shiferaw et al. 2019), accessibility to infrastructure/markets and water availability or climate.

The LULC change analysis revealed that LULC types particularly important for the ecosystem as well as peoples' livelihoods in the sub-basin, namely natural forest, woodland and grasslands, have substantially decreased in the last 30 years. This reflects a general trend found in studies conducted in similar biomes in different parts of the world, e.g. in Australia (Cleugh et al. 2012), China (Li et al. 2007), Mozambique (Niquisse et al. 2017), as well as in different parts of Ethiopia (Gashaw et al. 2018; Hurni 


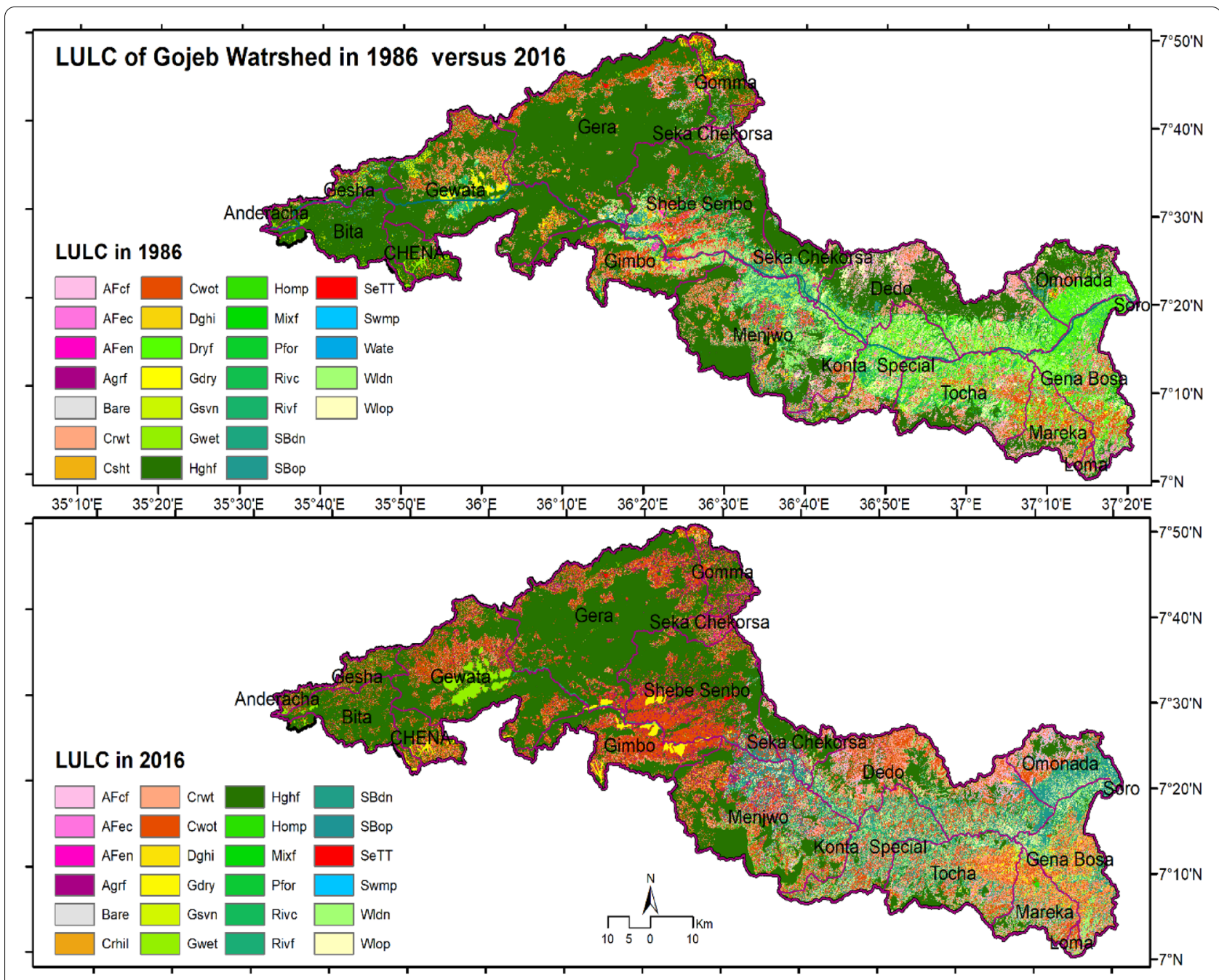

Fig. 2 Land transformation between 1986 and 2016 in the Gojeb watershed, Omo-Gibe sub-basin, Ethiopia

Table 2 LULC transformation/dynamics within the last 30 years

\begin{tabular}{|c|c|c|c|c|c|c|c|}
\hline \multirow{2}{*}{$\begin{array}{l}\text { Major Land use } \\
\text { cover types }\end{array}$} & \multicolumn{2}{|l|}{1986} & \multicolumn{2}{|l|}{2016} & \multicolumn{3}{|c|}{ Change between 1986 and 2016) } \\
\hline & Area (ha) & $\%$ & Area (ha) & $\%$ & ha & $\%$ & $\begin{array}{l}\text { Annual change } \\
\text { rate (ha) }\end{array}$ \\
\hline Bareland & 14.5 & 0.002 & 1412 & 0.2 & 1397 & 0.2 & 47 \\
\hline Cropland & 150,144 & 21.4 & 258,394 & 36.8 & 108,251 & 15.4 & 3608 \\
\hline Grassland & 23,149 & 3.3 & 22,518 & 3.2 & -631 & -0.1 & -21 \\
\hline Forest & 423,055 & 60.3 & 317,308 & 45.23 & $-105,747$ & -15.1 & -3525 \\
\hline Plantation & 969 & 0.14 & 4670 & 0.67 & 3701 & 0.5 & 123 \\
\hline Settlement & 161 & 0.023 & 383 & 0.06 & 223 & 0.03 & 7.5 \\
\hline Shrub & 20,491 & 2.9 & 51,011 & 7.3 & 30,520 & 4.4 & 1017 \\
\hline Swamp & 971 & 0.12 & 822 & -0.14 & -149 & -0.02 & 5.1 \\
\hline Woodland & 82,791 & 11.8 & 44,929 & 6.4 & $-37,862$ & -5.4 & -1262 \\
\hline Total & 701,595 & 100 & 701,595 & 100 & - & - & - \\
\hline
\end{tabular}




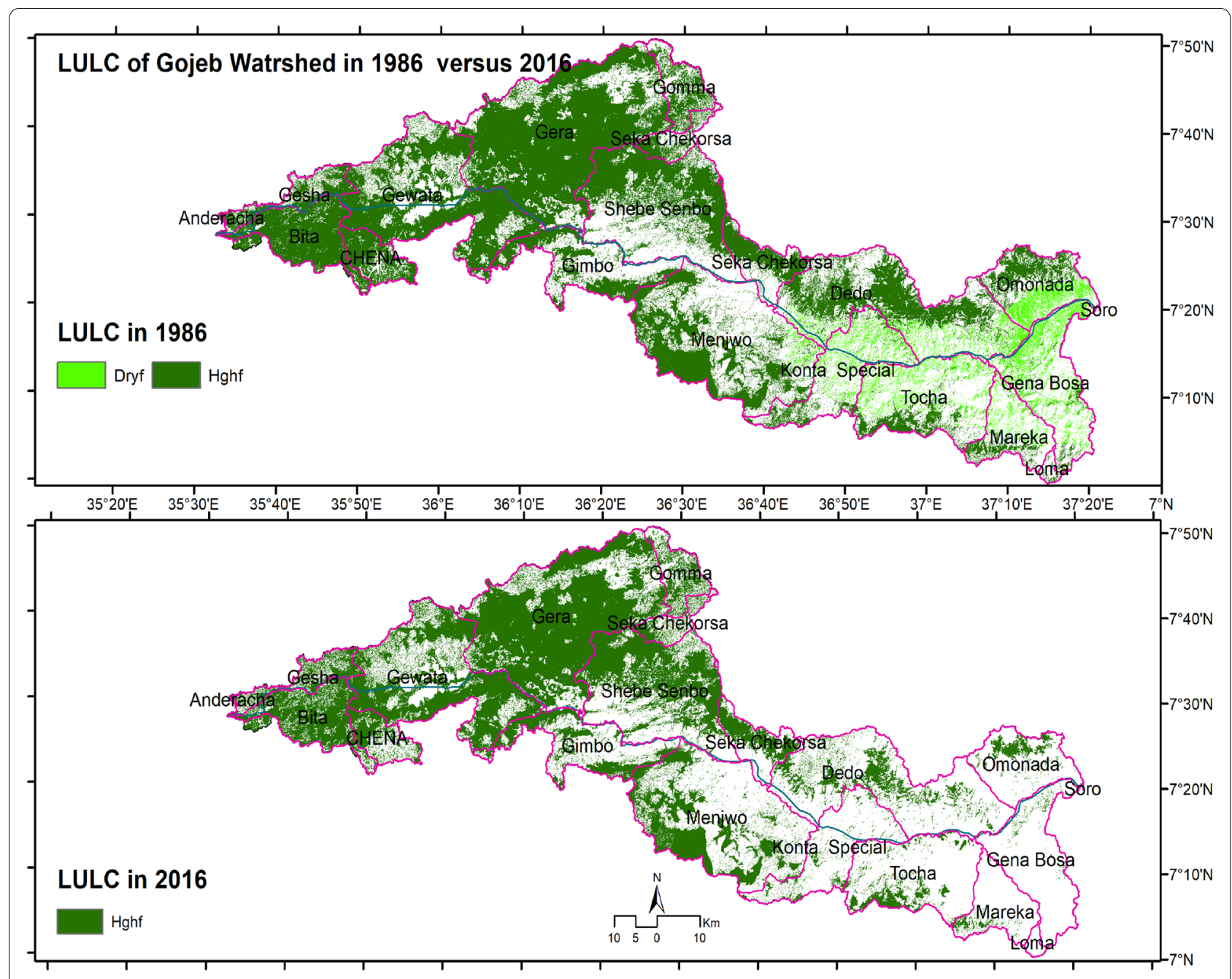

Fig. 3 Dry forest and high forest changes between 1986 and 2016 in the Gojeb watershed

Table 3 Transformation of LULC area (ha) in the sub-basin

\begin{tabular}{|c|c|c|c|c|c|c|c|c|c|c|}
\hline \multirow[t]{2}{*}{ LULC 1986} & \multicolumn{10}{|c|}{ LULC 2016} \\
\hline & Bare & Cultivate & Forest & Grass & Plantation & Shrub & Settlement & waterbody & Woodland & Total 1986 \\
\hline Bare & 2 & - & - & - & - & - & & & - & 2 \\
\hline Cultivated & 253 & 125,519 & 8883 & 5274 & 1932 & 4814 & 105 & - & 3351 & 150,131 \\
\hline Forest & 141 & 67,758 & 292,464 & 5232 & 2211 & 21,334 & 59 & & 24,168 & 413,367 \\
\hline Grass & 27 & 14,239 & 905 & 5377 & 52 & 801 & 1 & - & 755 & 22,157 \\
\hline Plantation & 1 & 392 & 312 & 76 & 20 & 115 & 5 & - & 45 & 966 \\
\hline Shrub & 90 & 12,431 & 787 & 410 & 72 & 5178 & 10 & - & 972 & 19,950 \\
\hline Settlement & - & 9 & 3 & 8 & - & 1 & 137 & & 2 & 160 \\
\hline waterbody & 11 & 284 & 36 & 156 & 25 & 13 & - & 149 & 18 & 543 \\
\hline Woodland & 76 & 37,746 & 3011 & 4370 & 357 & 18,751 & 66 & - & 15,621 & 79,998 \\
\hline Total2016 & 601 & 258,378 & 306,401 & 20,903 & 4669 & 51,007 & 383 & 149 & 44,932 & 687,274 \\
\hline
\end{tabular}


Table 4 Major LULC types and corresponding ESVs (US\$) within the last 30 years

\begin{tabular}{|c|c|c|c|c|c|c|}
\hline \multirow[t]{2}{*}{ Land use types } & \multicolumn{3}{|l|}{ Area (ha) } & \multicolumn{3}{|l|}{ ESVs (US) } \\
\hline & 1986 & 2016 & 2016-1986 & 1986 & 2016 & Net change (2016-1986) \\
\hline Bareland & 14.5 & 1411.8 & 1397 & - & - & - \\
\hline Cropland & $150,143.6$ & $258,394.4$ & 108,251 & $33,932,449$ & $58,397,137$ & $24,464,688$ \\
\hline Grassland & $23,148.6$ & $22,517.7$ & -631 & $96,437,193$ & $93,808,863$ & $-2,628,329$ \\
\hline Forest & $423,055.2$ & $317,308.1$ & $-105,747$ & $2,276,882,925$ & $1,707,751,925$ & $-569,131,000$ \\
\hline Plantation & 968.9 & 4669.5 & 3701 & - & - & - \\
\hline Settlement & 160.6 & 383.4 & 223 & $1,069,490$ & $2,553,827$ & $1,484,337$ \\
\hline Shrub & $20,490.5$ & $51,010.5$ & 30,520 & $20,224,104$ & $50,347,334$ & $30,123,230$ \\
\hline Waterbody & 822.1 & 970.6 & 149 & $10,284,489$ & $12,143,647$ & $1,859,158$ \\
\hline Woodland & $82,790.8$ & $44,928.7$ & $-37,862$ & $81,714,539$ & $44,344,647$ & $-37,369,893$ \\
\hline Total/net & $701,594.64$ & $701,594.64$ & & $2,520,545,189$ & $1,969,347,380$ & $-551,197,809$ \\
\hline \multicolumn{4}{|c|}{ Annual ESVs change (US\$/year) } & & & - 18.4 million \\
\hline \multicolumn{4}{|c|}{ Annual rate per ha (US\$/ha/year) } & & & -26.2 \\
\hline
\end{tabular}

et al. 2005; Kindu et al. 2016; Shiferaw et al. 2019; Tolessa et al. 2017; Tsegaye et al., 2010), but also at the global level (Costanza et al. 1997, 2014).

A shift of grassland to bareland, however, is likely to be a combination of overexploitation of forests. An ever increasing deforestation resulted in high erosion and sediment load of 20.7 ton/ha/year over the catchment, which is equivalent with an annual sediment influx of 14.5 million tons/year for the sub-basin (Yilikal 2019) that enters to Gibe III hydroelectric dam at the downstream.

Between 1960 and 2010, the population in Ethiopia has increased by 268\% (Pricope et al. 2013), and this has translated into higher livestock stocking rates. In recent years, trends in livestock numbers have become more variable but grazers have decreased and browsers increased (Yosef et al. 2013). Several 'anthropogenic' classes, such as cropland, settlements and bareland have also increased at the expense of natural vegetation cover. Similar trends of LULC changes towards more anthropogenic land use categories were found in other studies conducted in Eastern Africa, with cropland and settlements increasing at the expense of forests, shrubland and grasslands (Eckert et al. 2017; Shiferaw et al. 2019; Tolessa et al. 2017; Zewdie and Csaplovics 2015). In general, these spatial and temporal analyses and control their processes are important to help manage, restore, rehabilitate and protect environmental resources so as to maintain the quality and quantity ecosystem services provisions (Yilikal 2019).

\section{Ecosystem service values and implications}

Since all ESV estimates are based on studies from the study area itself or areas from the same biome (Olson et al. 2001), but not necessarily from the same topographic settings, we estimated the ESVs on the present study based on the coefficients used in different studies in the tropical regions (Costanza et al. 2014; Kiundu et al. 2016, Shiferaw et al. 2019). In the present study, the ESVs dropped annually by US\$ 18.4 million over 30 years (or $26.2 \mathrm{USS} \mathrm{ha}^{-1} \mathrm{y}^{-1}$ ) while Kindu et al. (2016) estimated that in a 10,000 ha area in the Ethiopian highlands, ESVs had dropped over the last 40 years by

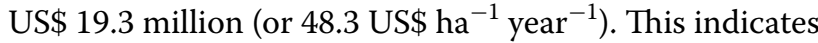
that the study area is relatively better in ESVs than the central highlands where there is high population pressure. Hence, restoring the area before it gets worse would cost less unlike other degraded parts of the country.

Several large scale agricultural investments have already been established in recent years in the sub-basin. This development will have a substantial impact on future LULC changes and ESVs. In addition, the expansion of investment programs both in the upper and downstream is expected to consume large areas of seasonal grasslands, forest and shrub/bushland (Shiferaw, personal observation). It is likely that ESVs from cropland will also further increase in the future due to a growing need for food and thus expansion of crop production in order to nourish the increasing population (Niquisse et al. 2017) though cropland has much lower ESVs than forest.

The average annual loss in ESVs Gojeb sub basin is more than fourfold of the annual budget of the whole zone in 2016/17 where the basin is a small part of the zone (BoFED 2017). This suggests that changes in ESVs should be considered as one of the indicators of stability of socio-ecological systems, human welfare and hence their assessment should be considered as a policy instrument (Niquisse et al. 2017) in the study area as well as elsewhere exhibiting with the same challenges. 
Mainstreaming ES and its values into policy and decision making is dependent on the availability of spatially explicit information on the state and trends of ecosystems and their services (Maes et al. 2012). Moreover, there is a need for designing restoration and/or rehabilitation programs to make the area resilient to climate change, frequent drought and also flood impacts so that sustainable ES and functions are maintained. Together with the implementation of sustainable forest, woodland and grassland management practices will be fundamental for preserving or even restoring the remaining ESVs in the study area and other regions in Eastern Africa.

\section{Conclusion}

The land use land cover transformation was very dynamic within the last 30 years in Gojeb watershed. The major LULC transformations were found from high and dry forest, shrubland and woodland areas to open woodland, cultivated land, settlement agroforestry and bareland. These have been happened mainly around the middle and eastern part of the basin. On the other hand, bareland, cropland, plantation and shrubland areas increased. The major ES providing land use types were decreased in areas as well as in ESVs: grassland, forest and woodland areas. Hence, Gojeb watershed has been lost ESVs of US\$ 18.4 million every year. Potential drivers could be agricultural expansion, land degradation and erosion, landslide and deforestation, indicating that it requires concerted effort to overcome such impacts. Therefore, restoration schemes should account the baseline land use/cover types so that soil seedbank could support rehabilitation or restoration effort with some additions of seeds or afforestation. This can enhance economic and ecosystem services from forest including carbon stock and biodiversity richness. Moreover, hydropower plants in the downstream will also benefit from upper catchment rehabilitation in terms of renewable energy production for domestic use and regional markets. Thus, this study is meaningful for management of natural resources in the catchment, improvement of hydropower production and lifespan of the hydropower reservoir. Similarly, smallholder farmers and other nature-based service provision actors could benefit from basin restoration if conservation efforts are made effectively to rehabilitate the upper catchment for the benefits of both upper catchment users (smallholder farmers) and lower catchment activities (e.g., hydropower) as hydrological cycles and biodiversity components of the catchment can be improved. Furthermore, the lesson learned from the study and subsequent recommendation for habitat restoration through payment for ecosystem services can be considered as a win-win approach to be implemented between upper and downstream users for sustainable use of resources.

\section{Appendix 1}

See Table 5.

Table 5 Biome equivalent of LULC types identified in this study and corresponding ESV coefficients based on global estimates. ESV coefficients are given in US\$ ha ${ }^{-1} \mathrm{y}^{-1}$

\begin{tabular}{lll}
\hline Biome equivalent LULC Type & $\begin{array}{l}\text { ESV coefficients } \\
\left(\text { US\$ ha } \mathbf{~ h}^{-1} \mathrm{y}^{-1}\right.\end{array}$ & Sources \\
\hline Bareland & - & Costanza et al. (2014), Kindu et al. (2016) \\
Cropland & 5567 & Kindu et al. (2016), Costanza et al. (2014) \\
Grassland & 4166 & Kindu et al. (2016), Shiferaw et al. (2019) \\
Natural forest & 5382 & Costanza et al. (2014), Kindu et al. (2016) \\
Plantation & 987 & Shiferaw et al. (2019) \\
Settlement & 6661 & Costanza et al. (2014) \\
Shrub/bush & 987 & van der Ploeg and de Groot (2010), Kindu et al. (2016) \\
Waterbodies (rivers) & 12,512 & Costanza et al. (2014), Tolessa et al. (2017) \\
Woodland & 987 & Kindu et al. (2016), Shiferaw et al. (2019)
\end{tabular}




\section{Acknowledgements}

The authors acknowledge Water and Land Resource Centre of Addis Ababa University for supporting field work and data analysis environment.

\section{Authors' contributions}

HS conceived the idea, collect relevant data, analyzed data and wrote the draft manuscript, TA supported field work and wrote the manuscript, TK carried out LULC analysis, and GZ supported the overall progress. All authors contributed in final writing.

\section{Funding}

No applicable.

\section{Availability of data and materials}

Not applicable.

\section{Declarations}

Ethics approval and consent to participate

Not applicable.

\section{Consent for publication}

We received a consent for waiving of publication processing fee from ENSR.

\section{Competing interests}

Authors declare that there is no conflict of interests.

Received: 27 January 2021 Accepted: 8 March 2021

Published online: 18 March 2021

\section{References}

Alo A, Pontius G (2008) Identifying systematic land-cover transitions using remote sensing and GIS: the fate of forests inside and outside protected areas of Southwestern Ghana. Environ Plan B Plan Des 35:280-295. https://doi.org/10.1068/b32091

Arowolo O, Deng X, Olatunji A, Obayelu E (2018) Assessing changes in the value of ecosystem services in response to land-use/land-cover dynamics in Nigeria. Sci Total Environ 636:597-609

Bagstad J, Johnson W, Voigt B, Villa F (2013) Spatial dynamics of ecosystem service flows: a comprehensive approach to quantifying actual services. Ecosyst Serv 4:117-125. https://doi.org/10.1016/j.ecoser.2012.07.012

BoFED, (2017) Annual planning for 2016/17. Bureau of Finance and Economic Development, MoFED, Addis Ababa

Braat C, Groot D (2012) The ecosystem services agenda: bridging the worlds of natural science and economics, conservation and development, and public and private policy. Ecosyst Serv 1:4-15. https://doi.org/10.1016/j. ecoser.2012.07.011

Cleugh A, Leuning R, Mu Q, Running W, Teixeira C, Bastiaanssen, et al (2012) Developing land cover and land use data sets for the Australian continent - a collaborative approach. Remote Sens Environ 1:343-354. https:// doi.org/10.1016/j.proenv.2012.01.162

Costanza R, Arge R, De GR, Farberk S, Grasso M, Hannon B et al (1997) The value of the world's ecosystem services and natural capital. Nature 387:253-260. https://doi.org/10.1038/387253a0

Costanza R, de Groot R, Sutton P, van der Ploeg S, Anderson SJ, Kubiszewski . et al (2014) Changes in the global value of ecosystem services. Glob Environ Chang 26:152-158. https://doi.org/10.1016/j.gloenvcha.2014.04.002

CSA (2016). Annual demographic survey report. Central Statistical Agency (CSA), Addis Ababa.

Eckert S, Kiteme B, Njuguna E, Zaehringer G (2017) Agricultural expansion and intensification in the foothills of Mount Kenya: a landscape perspective. Remote Sens 9:1-20. https://doi.org/10.3390/rs9080784

Fu B, Wang Y, Xu P, Yan K, Li M (2014) Value of ecosystem hydropower service and its impact on the payment for ecosystem services. Sci Total Environ 472:338-346

Gashaw T, Tulu T, Argaw M, Worqlul W, Tolessa T, Kindu M (2018) Estimating the impacts of land use/land cover changes on ecosystem service values: the case of the Andassa watershed in the Upper Blue Nile basin of Ethiopia. Ecosyst Serv 31:219-228. https://doi.org/10.1016/j.ecoser.2018.05.001 Goldman-Benner L, Benitez S, Boucher T, Calvache A, Daily G, Kareiva P et al (2012) Water funds and payments for ecosystem services: practice learns from theory and theory can learn from practice. Oryx 46:55-63. https:// doi.org/10.1017/S0030605311001050

Grêt-Regamey A, Weibel B, Kienast F, Rabe S, Zulian G (2015) A tiered approach for mapping ecosystem services. Ecosyst Serv 13:16-27. https://doi.org/ 10.1016/j.ecoser.2014.10.008

Hulme E, Burslem P, Dawson W, Edward E, Richard J, Trevelyan R (2013) Plant Invasions in Protected Areas. Springer, Dordrecht Heidelberg New York London. https://doi.org/10.1007/978-94-007-7750-7(ISBN978-94-0077749-1ISBN978-94-007-7750-7(eBook))

Hurni H, Tato K, Zeleke G (2005) The implications of changes in population, land use, and land management for surface runoff in the Upper Nile Basin Area of Ethiopia. Mt Res Dev 25:147-154. https://doi.org/10.1659/ 0276-4741(2005)025[0147:TIOCIP]2.0.CO;2

Homer C, Gallant A (2000) Partitioning the conterminous United States into mapping zones for landsat TM land cover mapping. South Dakota, USA

Jensen JR (1996) Introductory digital image processing: a remote sensing perspective. Prentice-Hall Inc, Eaglewood Cliff

Kassawmar et al. (2016a) Land use LAND cover classification between 1986 and 2016. Draft report, Addis Ababa, Ethiopia

Kassawmar T, Eckert S, Hurni K, Zeleke G, Hurni H (2016b) Reducing landscape heterogeneity for improved land use and land cover (LULC) classification across the large and complex Ethiopian highlands. Geocarto Int 33:53-69. https://doi.org/10.1080/10106049.2016.1222637

Kindu M, Schneider T, Teketay D, Knoke T (2016) Changes of ecosystem service values in response to land use/land cover dynamics in MunessaShashemene landscape of the Ethiopian highlands. Sci Total Environ 547:137-147. https://doi.org/10.1016/j.scitotenv.2015.12.127

Kremer P, Hamstead Z, Haase D, McPhearson T, Frantzeskaki N, Andersson E et al (2016) Key insights for the future of urban ecosystem services research. Ecol Soc. https://doi.org/10.5751/ES-08445-210229

Lefcheck S, Byrnes K, Isbell F, Gamfeldt L, Griffin N, Eisenhauer N et al (2015) Nature communications biodiversity enhances ecosystem multifunctionality across trophic levels and habitats. Nat Commun 6:1-7. https://doi. org/10.1038/ncomms7936

Leh D, Matlock D, Cummings C, Nalley L (2013) Quantifying and mapping multiple ecosystem services change in West Africa. Agric Ecosyst Environ 165:6-18

Li Q, Dong M, Cui Y, Zhang L, Cui G, He M (2007) Quantification of the impact of land use changes on ecosystem services: a case study in Pingbian County, China. Environ Monit Assess 128:503-510. https://doi.org/10. 1007/s10661-006-9344-0

Liu C, White M, Newell G (2009) Measuring the accuracy of species distribution models: a review. In: 18th World IMACS/MODSIM Congr. Cairns, Aust. 13-17 July 2009, pp. 4241-4247.

Lu D, Mausel P, Brondizio E, Moran E (2002) International Journal of Assessment of atmospheric correction methods for Landsat TM data applicable to Amazon basin LBA. Int J Remote Sens 23:2651-2671. https://doi.org/ 10.1080/01431160110109642

Maes J, Egoh B, Willemen L, Liquete C, Vihervaara P, Grizzetti B et al (2012) Mapping ecosystem services for policy support and decision making in the European Union. Ecosyst Serv 1:31-39. https://doi.org/10.1016/j.ecoser. 2012.06.004

Nelson E, Mendoza G, Regetz J, Polasky S, Tallis H, Cameron R et al (2009) Modeling multiple ecosystem services, biodiversity conservation, commodity production, and tradeoffs at landscape scales. Front Ecol Environ 7:4-11. https://doi.org/10.1890/080023

Niquisse S, Cabral P, Rodrigues Â, Augusto G (2017) Ecosystem services and biodiversity trends in Mozambique as a consequence of land cover change. Int J Biodivers Sci Ecosyst Serv Manag 13:297-311. https://doi. org/10.1080/21513732.2017.1349836

Olecka A (2003) Evaluating classifiers' performance in a constrained environment. Assoc Comput Mach KDD 2002:605-612. https://doi.org/10.1145/ 775107.775137

Olson M, Dinerstein E, Wikramanayake D, Burgess D, Powell N, Underwood C, et al. (2001) Terrestrial ecoregions of the world: a new map of life on Earth. Bioscience 51: 933-938 [online] URL: http://worldwildlife.org/publi cations/terrestrialecoregions- of-the-world. 
Pricope N, Husak G, Lopez-Carr D, Funk C, Michaelsen J (2013) The climate population nexus in the East African Horn: emerging degradation trends in rangeland and pastoral livelihood zones. Glob Environ Chang 23:1525-1541

Puyravaud P (2003) Standardizing the calculation of the annual rate of deforestation. For Ecol Manag 177:593-596. https://doi.org/10.1016/S03781127(02)00335-3

Lu N, Ramsey D (2015) Land cover dynamics monitoring with Landsat data in Kunming, China: a cost-effective sampling and modelling scheme using Google Earth imagery and random forests. Geocarto Int 30:186-201. https://doi.org/10.1080/10106049.2014.894583

Renison D, Hensen I, MCingolani A, (2004) Anthropogenic soil degradation affects seed viability in Polylepis australis mountain forests of central Argentina. For Ecol Manage 196:327-333

Scholes J, Montanarella L, Brainich E, Barger N, Ten Brink B, Cantele M et al (2018) IPBES: summary for policymakers of the assessment report on land degradation and restoration of the intergovernmental science-policy platform on biodiversity and ecosystem services. IPBES Secretariat, Bonn

Shackleton C, Ruwanza S, Sanni G, Bennett S, Lacy P, Modipa R, Mtati N, Sachikonye M, Thondhlana G (2016) Unpacking Pandora's Box: understanding and categorising ecosystem disservices for environmental management and human wellbeing. Ecosystems 19:587-600

Shiferaw H, Bewket W, Alamirew T, Zeleke G, Teketay D, Bekele K, Schaffner U, Eckert S (2019) Implications of land use/land cover dynamics and Prosopis invasion on ecosystem service values in Afar Region, Ethiopia. Sci Total Environ 675:354-366

Silvestri S, Zaibet L, Said Y, Kifugo C (2013) Valuing ecosystem services for conservation and development purposes: a case study fromKenya. Environ Sci Pol 31:23-33

Sutton P, Anderson S, Costanza R, Kubiszewski I (2016) The ecological economics of land degradation: impacts on ecosystem service values. Ecol Econ 129:182-192

TEEB (2010) The economics of ecosystems and biodiversity: mainstreaming the economics of nature: a synthesis of the approach, conclusions and recommendations of TEEB. Progress Press, Malta 978-3-9813410-3-4 Layouted by. www.dieaktivisten.de
Temesgen H, Wu W, Shi X, Yirsaw E, Bekele B, Kindu M (2018) Variation in ecosystem service values in an agroforestry dominated landscape in Ethiopia: implications for land use and conservation policy. Sustainability 10:11-26. https://doi.org/10.3390/su10041126

Tilahun M, Birner R, llukor J (2014) Households demand for mitigation of Prosopis juliflora invasion in the Afar region of Ethiopia: a contingent valuation. Manag. Prosopis juliflora Better Pastor. Livelihoods Horn Africa Proc. Reg. Conf. May 1-May 2, 2014, Addis Ababa, Ethiop. 0568 Doi: https://doi. org/10.1080/09640568.2016.1152955

Tolessa T, Senbeta F, Abebe T (2017) Land use/land cover analysis and ecosystem services valuation in the central highlands of Ethiopia. For Trees Livelihoods 26:111-123. https://doi.org/10.1080/14728028.2016.1221780

Van der Ploeg S, De Groot S, Wang Y (2010) The TEEB valuation database: overview of structure. Foundation for Sustainable Development, Wageningen, the Netherlands, Data and Results

Vaz A, Kueffer C, Kull A, Richardson D, Vicente J, Kühn I, Schröter M, Hauck J, Bonn A, Honrado J (2017) Integrating ecosystem services and disservices: insights from plant invasions. Ecosyst Serv 23:94-107. https://doi.org/10. 1016/j.ecoser.2016.11.017

Yilikal A (2019) Gojeb sub-catchment hydro-sediment assessment. Report to WRI and EFCCC, Addis Ababa

Yosef T, Mengistu U, Solomon A, Mohammed K, Kefelegn K (2013) Camel and cattle population dynamics and livelihood diversification as a response to climate change in pastoral areas of Ethiopia. Livest Res Rural Dev 25(9):1-10

Zewdie W, Csaplovics T (2015) Remote Sensing based multi-temporal land cover classification and change detection in northwestern Ethiopia. Eur J Remote Sens 48:121-139. https://doi.org/10.5721/EuJRS20154808

\section{Publisher's Note}

Springer Nature remains neutral with regard to jurisdictional claims in published maps and institutional affiliations.

\section{Submit your manuscript to a SpringerOpen ${ }^{\circ}$ journal and benefit from:}

- Convenient online submission

- Rigorous peer review

- Open access: articles freely available online

- High visibility within the field

- Retaining the copyright to your article

Submit your next manuscript at $\boldsymbol{\nabla}$ springeropen.com 